\title{
Evaluation of Solids, Nitrogen, and Phosphorus Excretion Models for Lactating Dairy Cows
}

\author{
M. Hollmann, ${ }^{1}$ K. F. Knowlton, and M. D. Hanigan ${ }^{2}$ \\ Department of Dairy Science, Virginia Polytechnic Institute and State University, Blacksburg 24061
}

\begin{abstract}
Monitoring or accurately predicting manure quantities and nutrient concentrations is important for dairy farms facing strict environmental regulations. The objectives of this project were to determine the daily outflow of manure nutrients from a free-stall barn using mass balance and to compare results with published excretion models. The project was conducted at the freestall facility housing the lactating cow herd of the Virginia Tech Dairy Center in 2005. The herd consisted of $142( \pm 8.9)$ Holstein and Jersey cows with a mean body weight of $568( \pm 6.2) \mathrm{kg}$ and average milk yield of 29.8 $( \pm 1.7) \mathrm{kg} / \mathrm{d}$ with $3.18 \%( \pm 0.07)$ true protein and $3.81 \%$ $( \pm 0.13)$ milk fat on 18 sampling days. The intakes of dry matter $(\mathrm{DM}), \mathrm{N}$, and $\mathrm{P}$ were estimated from the formulated ration. Daily consumption averaged 21.7 $( \pm 0.27) \mathrm{kg}$ of DM with $17.7 \%( \pm 0.26)$ crude protein and $0.46 \%( \pm 0.03)$ P. Approximately $110( \pm 27.9) \mathrm{kg} / \mathrm{d}$ of sawdust was used as bedding; its contribution to manure flow was subtracted. The alleys in the free-stall barn were flushed every $6 \mathrm{~h}$ with recycled wastewater, and the slurry was collected. On 18 sampling days the volumes and constituents of the flushwater and the flushed manure were determined for a 6 -h flush cycle and extrapolated to daily values. Net daily flow of solids and nutrients in manure were calculated as the differences between masses in flushed slurry and flushwater. Nitrogen and P excretion were also calculated from dietary inputs and milk output. The flow was compared with the American Society of Agricultural Engineers' (ASAE) standards. Each cow produced $5.80 \mathrm{~kg} / \mathrm{d}$ of total solids (remainder after drying at $105^{\circ} \mathrm{C}$ ). The ASAE standard predicted DM (remainder after drying at $60^{\circ} \mathrm{C}$ ) excretion of 8.02 to $8.53 \mathrm{~kg} / \mathrm{d}$ per cow. Recovery of $\mathrm{P}$ amounted to $74.8 \mathrm{~g} / \mathrm{d}$ per cow. Overall, $102 \%$ of intake $\mathrm{P}$ was recovered; $75.1 \%$ in the manure outflow and $26.9 \%$ in milk. About $285 \mathrm{~g} / \mathrm{d}$ and $148 \mathrm{~g} / \mathrm{d}$ of N per
\end{abstract}

Received August 10, 2007.

Accepted November 23, 2007.

${ }^{1}$ Current address: Dept. Animal Science, Michigan State University, East Lansing 48824.

${ }^{2}$ Corresponding author: mhanigan@vt.edu cow were recaptured in manure and milk, respectively; $182 \mathrm{~g} / \mathrm{d}$ was presumably volatilized. All models of $\mathrm{N}$ excretion appeared to underestimate $\mathrm{N}$ excretion. Volatilization rate of $\mathrm{N}$ amounted to $18.1 \% / \mathrm{h}$ for the $6-\mathrm{h}$ flush interval. Measured outflow of manure-P from the facility was similar to excretion predictions. Presentation of excreted solids as both total solids and DM is warranted. We conclude that using excretion prediction equations is useful for predicting excretion and outflow of $\mathrm{P}$ in a lactating cow facility, but $\mathrm{N}$ excretion predictions exhibited bias and have to be used prudently for predicting $\mathrm{N}$ outflow and $\mathrm{N}$ volatilization.

Key words: dairy barn mass nutrient balance, manure production, nitrogen volatilization

\section{INTRODUCTION}

Multiple researchers in the field of dairy cattle nutrition have established a variety of equations to predict excretion of solids or DM and nutrients such as $\mathrm{N}$ and P from dairy cattle (Van Horn et al., 1994; Nennich et al., 2005; Yan et al., 2006). Engineers develop and design manure storage and treatment systems based on manure composition and characteristics, which are published as American Society of Agricultural Engineers (ASAE) standards (ASAE, 1999, 2005). The dairy cattle excretion predictions in the most recent standard (ASAE, 2005) were based on meta-analyses of totalcollection studies across the United States (Nennich et al., 2005). Yet there is a lack of connection in the scientific literature between the manure excreted and the actual composition of manure being stored. Use of manure compositional data derived from excretion models to estimate amounts of nutrients stored may be more logical and comprehensible than the existing division among disciplines.

Furthermore, predicting manure outflow from a facility based on excretion models would allow estimation of volatilization losses. As a specific example, the difference of $\mathrm{N}$ input into the system (the lactating cow facility) via feed and bedding and the measured $\mathrm{N}$ outflow from the system in milk and manure is presumably volatilized. Moreira and Satter (2006) used the nonvolatile manure- $\mathrm{P}$ as a marker to quantify $\mathrm{N}$ volatilization 
from manure. Their approach of tracking the N:P ratio does not require measurement of manure volume. Application of this method to a variety of systems will provide much needed data regarding expected $\mathrm{N}$ volatilization across a variety of facilities and management strategies. The National Research Council favors such a process-based approach (NRC, 2003).

Nonetheless, there are various approaches of estimating $\mathrm{N}$ and $\mathrm{P}$ excretion in the literature besides the balance approach (i.e., $\mathrm{N}$ or $\mathrm{P}$ intake equals the sum of $\mathrm{N}$ or $\mathrm{P}$ secreted in milk and excreted in manure; Weiss and Wyatt, 2004; Nennich et al., 2005; Yan et al., 2006). Consequently, and to take the approach of Moreira and Satter (2006) further, we compared the actual recovered amounts of solids, $\mathrm{N}$, and $\mathrm{P}$ in the manure outflow from a lactating cow facility with previously published excretion models. The objectives were first, to validate the accuracy of our methods by accounting for all $\mathrm{P}$ inflow in the outflow from the system; second, to estimate overall volatilization and an average hourly volatilization rate of $\mathrm{N}$; and third, to evaluate the use of excretion predictions for their potential use in future processbased models.

\section{MATERIALS AND METHODS}

\section{Herd and Manure Handling System}

The study was conducted at the lactating cow facility of the Virginia Tech Dairy Center (Blacksburg, VA). The herd, consisting of Jersey and Holstein dairy cows, was milked twice daily at 0130 and $1330 \mathrm{~h}$ and fed a TMR once daily at $1000 \mathrm{~h}$. The orts were removed daily. The free-stall barn was set up as a head-to-head design with 4 manure alleys. Mattresses covered the stalls and were bedded with kiln-dried sawdust. The amount of added bedding was recorded. The manure alleys along the feed bunk and the outside measured $4.27 \mathrm{~m}$ and $3.66 \mathrm{~m}$ in width, respectively, and were $118 \mathrm{~m}$ long with a slope of $2 \%$. Two steel silos with an inside diameter of $3.62 \mathrm{~m}$ and a filling-height of $8.6 \mathrm{~m}$ stored the recycled or gray water used to gravity-flush the 4 alleys and the holding pen. The alleys were flushed 4 times a day at 6-h intervals; the holding pen was flushed after each milking. Each alley flush lasted for $40 \mathrm{~s}$. The flush volume was measured indirectly via pressure transducers (Pressure Systems, Hampton, VA), which were firmly installed on the bottom of each silo, and recorded on a CR-10 data logger (Campbell Scientific Inc., Logan, UT) for each silo. The flushed slurry from the alleys and the wastewater from the milking parlor were collected in a trench along the lower end of the barn and diverted into a collection pit. The slurry was agitated and pumped onto a liquid-solid separator (Nutrient Control System Inc., Chambersburg, PA). Separated solids were removed from the cycle, whereas the liquids drained into 1 of 2 parallel settling basins with a combined volume of $300 \mathrm{~m}^{3}$. The settling basins turned over about once every $36 \mathrm{~h}$. The liquids from the basins flowed by gravity into the first of 3 storage tanks. The first 2 tanks had a diameter of $28.2 \mathrm{~m}$ and the final tank had a diameter of $38.6 \mathrm{~m}$; each had a maximum fill height of $3.35 \mathrm{~m}$. An aerator in each tank forced air into the top layer of the wastewater. Liquids were pumped from a depth of about $50 \mathrm{~cm}$ below the surface from the first into the second, and into the third tank, from where it was either pumped back into the flush silos or irrigated on adjacent farm land.

\section{Sample Collection}

The inflow and outflow of flushwater from a single flush cycle (manure accumulated from 1200 to $1800 \mathrm{~h}$ ) was monitored every other week from January to May and monthly for the rest of 2005 for a total of 18 sampling days. The flush cycle chosen included the afternoon milking shift and thus effluents from the freestall area and the parlor and holding pen were assessed. One sampling day in early April had missing values for the flushwater usage due to data logger failure and, consequently, could not be used for this analysis. A sampling cycle in May produced outlying $\mathrm{P}$ readings (more than 3 standard deviations from the mean) and was excluded from the $\mathrm{P}$ observations.

The collection pit was pumped as low as possible after the $1200 \mathrm{~h}$ flush cycle on each sampling day. The depth of the remainder (generally about $15 \mathrm{~cm}$ ) was measured with a tape and a representative sample was taken. Wastewater from the parlor and flushwater from the holding pen were collected in the pit during the regular afternoon milking. After milking and cleaning of the parlor and holding pen, the depth of the collected liquids in the collection pit was measured, the liquids were agitated for 2 min, and a pooled sample of 3 column samples was obtained. Thereafter, the pit was again pumped out, and the depth of the remainder was measured. The $1800 \mathrm{~h}$ flush of the 4 manure alleys was collected and sampled in an identical manner. A sample of the flushwater was obtained by pooling several subsamples taken from a T-valve in the pipe feeding the flushwater silos during refilling after the previous 1200 $\mathrm{h}$ flush. The gross amounts of solids and nutrients leaving the facility were calculated by subtracting the total amounts in the pit before the flushes from the total amounts after the flushes. Net contributions of manure were determined by subtracting the nutrients present in the flushwater from the amounts in the effluent leaving the barn. The sum of volumes and constituents from the parlor and the barn flush represented the 6-h sam- 
pling interval. Daily manure production was calculated by multiplication of the measured nutrient accumulation for the interval by 4 , assuming evenly distributed nutrient excretions throughout the day.

Intake of $\mathrm{DM}, \mathrm{N}$, and $\mathrm{P}$ were calculated from the ration formulated for each individual sampling day. Forage samples were taken periodically throughout the year, submitted for analyses, and used for ration formulation purposes. Thus, formulated nutrients should be a representative sampling of the feed composition. Records from the dairy plant were utilized to determine milk contents of fat, true protein, and MUN. Milk P concentration was assumed to be $0.09 \%$ (NRC, 2001) and was verified in an independent, concurrent study using a total of 88 milk samples from 18 cows in the same herd [M. S. Taylor, K. F. Knowlton, M. L. McGilliard, W. S. Swecker, M. D. Hanigan (Virginia Tech.); J. D. Ferguson and Z. Wa (Univ. Pensylvania); unpublished data]. Milk production and BW data were acquired with AfiFarm version 3.01 (SAE Afikim, Kibbutz Afikim, Israel).

\section{Sample Analysis}

All wastewater subsamples were taken in duplicate, with one sample being acidified immediately with $\mathrm{H}_{2} \mathrm{SO}_{4}$ to a $\mathrm{pH}<2$. All samples were stored at $4^{\circ} \mathrm{C}$ at one time. The concentration of total solids was determined by drying $25 \mathrm{~mL}$ of unacidified sample at $105^{\circ} \mathrm{C}$ to a constant weight. Acidified samples were analyzed for ammonia (phenate method), nitrate and nitrite (APHA, 1998), and total Kjeldahl N concentrations using a Foss Tecator analyzer (2400 Kjeltech Analyzer Unit, Foss Tecator AB, Hoganas, Sweden) and for total P (AOAC, 1990; APHA, 1998).

Reported values are arithmetic means of the observations. Student's $t$-test was used to compare these values against results from various prediction models, which were assumed to represent population means.

\section{RESULTS AND DISCUSSION}

The number of cows in the herd increased over the sampling period from 129 in January to 160 in December 2005, averaging 142 on sampling days across the year (Table 1). Bedding additions averaged 110 (SD $\pm 27.9) \mathrm{kg} / \mathrm{d}$ for the entire herd. The breed composition of the herd was relatively constant throughout the year averaging $31 \%$ Jerseys with the remainder being Holsteins, whereas the standard values were based solely on Holstein cows (Nennich et al., 2005). As a result, BW and milk yield per cow were lower, but milk fat and protein contents were higher in the current study compared with the means in the data set of the ASAE
(2005) standard (Table 1). The latest NRC (2001) predicts a DMI of $21.6 \mathrm{~kg} / \mathrm{d}$ for the herd. Estimated DMI of $21.7 \mathrm{~kg} / \mathrm{d}$ mirrored the DMI expected by NRC (2001) and reported in the data set used to derive the standards (Table 2). However, actual feed refusals were weighed infrequently in the current study. The herd nutritionists used the observed DMI from the infrequent weigh-backs to formulate diets. The nutritionist at the onset of the experiment assumed 10\% overfeeding, whereas his successor assumed 5\% refusals when formulating diets. Nonetheless, DMI is dependent on a variety of factors (Allen, 2000) including dietary NDF content, which was lower in the current study than the mean of the diets in the database for the ASAE (2005) standard (Table 2). Dietary contents of $\mathrm{N}$ and $\mathrm{P}$ were similar in both datasets (Table 2). Inputs of $\mathrm{N}$ and $\mathrm{P}$ via the bedding material were minute (Table 2 ), yet their amounts were subtracted from the calculated amounts of recovered constituents of the slurry.

\section{Excretion of Solids}

Recovered total solids (dried at $105^{\circ} \mathrm{C}$ ) of excreta averaged $5.80(\mathrm{SEM} \pm 0.37) \mathrm{kg} / \mathrm{d}$ per cow (Table 3). The engineering community frequently uses total solids in sizing and performance analyses of manure systems (ASAE, 1999). The initial aim of the current study was to evaluate the performance of the manure system; hence, samples were dried at $105^{\circ} \mathrm{C}$ in accordance with the engineering protocol. In contrast, animal scientists commonly express excreted manure on the basis of DM, as in the foundation database for the recent ASAE standard (2005). Dry matter estimation is based on forcedair drying of a sample at $60^{\circ} \mathrm{C}$. The $2005 \mathrm{ASAE}$ standard reports DM excretion but does not report excretion of total solids (ASAE, 2005), whereas the previous version (ASAE, 1999) cited excretion of total solids but not DM. These differences in method complicate comparisons across disciplines and time.

Three equations are published in the 2005 ASAE standard to predict excreted $\mathrm{DM}\left(\mathbf{D M}_{\mathbf{E}}\right)$ :

$$
\begin{gathered}
\mathrm{DM}_{\mathrm{E}}=\mathrm{MY}(\mathrm{kg} / \mathrm{d}) \times 0.0874+5.6 \\
\mathrm{DM}_{\mathrm{E}}=\mathrm{DMI}(\mathrm{kg} / \mathrm{d}) \times 0.356+0.80 \\
\mathrm{DM}_{\mathrm{E}}=\mathrm{MY}(\mathrm{kg} / \mathrm{d}) \times 0.112+\mathrm{BW} \\
\times 0.0062+\mathrm{MTP}[\mathrm{g} / \mathrm{g}] \times 106.0-2.2
\end{gathered}
$$

where MY and MTP represent milk yield and milk true protein, respectively.

Nennich et al. (2005) observed that using DMI [2] best predicted the DM excreted (residual $\mathrm{SE}=0.78$, 
Table 1. Descriptive parameters of the herd of lactating cows in the current study on sampling days compared with the data set utilized to establish prediction equations

\begin{tabular}{lcccccc}
\hline & \multicolumn{2}{c}{ Current data } & & \multicolumn{2}{c}{ Industry standard $^{1}$} & \\
\cline { 2 - 3 } Item & Mean & $\mathrm{SD}^{2}$ & & Mean & $\mathrm{SD}$ & $\mathrm{n}$ \\
\hline Cow data & & & & $\mathrm{NA}^{3}$ & $\mathrm{NA}$ & $\mathrm{NA}$ \\
Cows, $\mathrm{n}$ & 142 & 8.9 & & 630 & 56.1 & 554 \\
BW, kg & 568 & 6.2 & & & \\
DIM, d & 189 & 21.6 & & 172 & $\mathrm{NA}$ & $\mathrm{NA}$ \\
Daily output (milk) & & & & $\mathrm{NA}$ & 11.0 & 553 \\
Milk yield, kg/herd & 4,221 & 427.3 & & 31.4 & 0.16 & 529 \\
Milk yield, kg/cow & 29.8 & 1.69 & & 2.99 & 0.67 & 529 \\
Milk true protein, \% & 3.18 & 0.07 & & 3.62 & &
\end{tabular}

${ }^{1}$ Calculated from Nennich et al. (2005).

${ }^{2} \mathrm{SD}=$ deviation of the average measured at each sampling day.

${ }^{3} \mathrm{NA}=$ not available.

interstudy $\mathrm{SE}=1.11$ ), compared with using milk yield [1] (residual $\mathrm{SE}=1.21$, interstudy $\mathrm{SE}=0.87$ ) or milk yield, BW, and milk true protein content [3] (residual $\mathrm{SE}=1.15$, interstudy $\mathrm{SE}=0.78$ ). Using data from the current study, daily DM excretion was predicted at 8.53 $(\mathrm{SEM} \pm 0.02), 8.20( \pm 0.03)$, and $8.02( \pm 0.04) \mathrm{kg}$ per cow, respectively for [1], [2], and [3]. Thus, the observed solids excretion averaged $68.0 \%( \pm 4.3 \%), 70.7 \%( \pm 4.4 \%)$, and $72.4 \%( \pm 4.6 \%)$ of that predicted by the 3 equations, respectively. The difference between the predicted DM and observed solids excretion represents the mass volatilized between 60 and $105^{\circ} \mathrm{C}$, any errors of measurement including DMI, and bias in applying the equations to this herd.

The recovered total solids in the outflow were also significantly less than the $6.82-\mathrm{kg}$ total solids excretion that the 1999 ASAE standard predicted for the mean BW observed in the current study. The 1999 ASAE standard is based solely on BW and livestock species; it ignores any production data (ASAE, 1999). The overestimation of DM excretion with the 1999 equation may be partially due to its focus on BW as the exclusive driver of excretion. Many researchers have found a direct positive correlation of DMI and DM excretion (Nennich et al., 2005; Hindrichsen et al., 2006), and DMI is primarily driven by milk production, not BW, as reviewed by Allen (2000). Therefore, DMI should be a factor when predicting DM excretion in dairy cattle.

To our knowledge, no data exist in the scientific literature comparing DM excretion estimates to total solids excretion estimates. The former is often reported in nutritional studies, whereas the latter is used commonly by engineers evaluating and engineering manure systems. The 2 methods differ in the amount of moisture retained in the dry fraction and also differ in their repeatability. For example, the American Feed Industry Association (AFIA, 2007) reported that the National Forage Testing Association method 2.2.2.5

Table 2. Average daily inflow of DM, N, and $\mathrm{P}$ in the current study in contrast to the data set used to develop industry standard excretion formulas

\begin{tabular}{|c|c|c|c|c|c|}
\hline \multirow[b]{2}{*}{ Item } & \multicolumn{2}{|c|}{ Current data } & \multicolumn{2}{|c|}{ Industry standard ${ }^{1}$} & \multirow[b]{2}{*}{$\mathrm{n}$} \\
\hline & Mean & $\mathrm{SD}^{2}$ & Mean & SD & \\
\hline \multicolumn{6}{|l|}{ Daily input (feed) } \\
\hline DMI, kg/cow & 21.72 & 0.270 & 21.7 & 3.9 & 553 \\
\hline Dietary CP, \% & 17.67 & 0.255 & 17.5 & 1.85 & 529 \\
\hline Dietary $\mathrm{CP}, \mathrm{g}$ of $\mathrm{N} / \mathrm{d}$ & 614 & 8.4 & 608 & 1.2 & $\mathrm{NA}^{3}$ \\
\hline Dietary P, \% & 0.46 & 0.030 & 0.44 & 0.07 & 66 \\
\hline Dietary P, g/d & 99 & 6.2 & 95 & 2.7 & NA \\
\hline Dietary NDF, \% & 33.1 & 0.68 & 36.4 & 5.07 & 554 \\
\hline \multicolumn{6}{|l|}{ Daily input (bedding) } \\
\hline Solids, kg/cow & 0.77 & 0.227 & NA & NA & NA \\
\hline Total Kjeldahl N, g/cow & 0.40 & 0.107 & NA & NA & NA \\
\hline $\mathrm{P}, \mathrm{g} / \mathrm{cow}$ & 0.67 & 0.210 & NA & NA & NA \\
\hline
\end{tabular}

${ }^{1}$ Calculated from Nennich et al. (2005).

${ }^{2} \mathrm{SD}=$ deviation of the average measured at each sampling day.

${ }^{3} \mathrm{NA}=$ not available. 
Table 3. Outflow of solids, N, and P from the lactating cow facility in the present study compared with the excretion constituents of the data set used to develop industry standard excretion formulas

\begin{tabular}{lcccccr}
\hline & \multicolumn{2}{c}{ Current data } & & \multicolumn{2}{c}{ Industry standard $^{1}$} & \\
\cline { 2 - 3 } Item & Mean & SEM $^{2}$ & & Mean & SEM & \\
\hline Daily output (manure) & & & & & \\
Solids, ${ }^{3}$ kg/cow & 5.80 & 0.37 & & 8.52 & 0.08 & 538 \\
TKN excreted, ${ }^{4}$ g/cow & 466 & 3.4 & & 439 & 4.1 & 529 \\
TKN leaving barn, ${ }^{5}$ g/cow & 285 & 62.7 & & $\mathrm{NA}^{6}$ & $\mathrm{NA}$ & NA \\
P, g/cow & 75 & 4.2 & & 74 & 1.8 & 85 \\
\hline
\end{tabular}

${ }^{1}$ Calculated from: Nennich et al. (2005).

${ }^{2} \mathrm{SEM}$ refers to the error of the average measured or calculated at each sampling day.

${ }^{3}$ Solids are reported as total solids $\left(105^{\circ} \mathrm{C}\right)$ in the current study and as DM $\left(60^{\circ} \mathrm{C}\right)$ for the industry standard.

${ }^{4}$ Total Kjeldahl nitrogen (TKN) excreted was calculated from eq. [10] for the current data. The industry standard predicts "as-excreted" manure N using CP intake and BW (Nennich et al., 2005).

${ }^{5}$ Determined in slurry leaving the barn in the current study.

${ }^{6} \mathrm{NA}=$ not available.

(drying a feed sample at $105^{\circ} \mathrm{C}$ for $3 \mathrm{~h}$ ) had the lowest inter- and intralaboratory variations in analyzing DM in distillers grains with solubles among techniques tested. Reporting both $\mathrm{DM}$ (measured at $60^{\circ} \mathrm{C}$ ) and total solids (measured at $105^{\circ} \mathrm{C}$ ), may be warranted for ease of comparison between fields of study until a suitable method to analyze manure comparable to the AFIA method has been developed and evaluated. Unfortunately, the current work was initiated before publication of the current ASAE standard (ASAE, 2005), and thus only total solids were measured.

\section{Predicted Excretion and Recovery of $\boldsymbol{P}$}

Phosphorus input into the system (the lactating cow facility) consisted of dietary $\mathrm{P}$ and $\mathrm{P}$ supplied within bedding material. A mean $( \pm$ SEM) of $14.1( \pm 0.23) \mathrm{kg}$ of $\mathrm{P} / \mathrm{d}$ were added to the system, $14.0( \pm 0.23) \mathrm{kg}$ as intake of dietary $\mathrm{P}$ and $0.1( \pm 0.01) \mathrm{kg}$ via the bedding material. The sawdust bedding contained little $\mathrm{P}(0.3 \mathrm{~g} / \mathrm{kg})$ and supplied only minute amounts of $\mathrm{P}$ on the broad scale, as previously observed (Moreira and Satter, 2006). Measured $\mathrm{P}$ outflow from the system occurred in milk $[3.8( \pm 0.1) \mathrm{kg} / \mathrm{d}]$ and $\mathrm{P}$ recovered in the manure leaving the barn $[10.6( \pm 0.57) \mathrm{kg} / \mathrm{d}]$. The variance in both $\mathrm{P}$ inputs and $\mathrm{P}$ outputs was positively affected by the increase in cow numbers in the facility over the course of the study. The unaccounted $\mathrm{P}$ in the outflow may have resulted from the compounding errors of estimating DMI, negative net $\mathrm{P}$ retention, inaccuracy during preparation of the diet, and sampling errors of feedstuffs, manure, and flushwater. Nonetheless, the error was not different from $0[-0.3( \pm 0.56) \mathrm{kg} / \mathrm{d}]$.

Retention of $\mathrm{P}$ (for growth and replenishment of $\mathrm{P}$ storage) on a daily basis for a whole herd of cows in various stages of lactation is negligible (Van Horn et al., 1994; Beede and Davidson, 1999). The National
Research Council (2001) provides a computation of $\mathrm{P}$ retention for growth based on mature and actual BW. Mature BW used in the NRC model are $400 \mathrm{~kg}$ for Jersey and $650 \mathrm{~kg}$ for Holstein cows; however, cows in the current study weighed 400 and $610 \mathrm{~kg}$ across all lactations on the last sampling day. Consequently, we estimated the mature BW for the present herd at 425 and $645 \mathrm{~kg}$, respectively. Given the distribution of breeds (31\% Jersey), the composite mature BW was calculated at $580 \mathrm{~kg}$. According to NRC (2001), $5.9 \mathrm{~g}$ of $\mathrm{P} / \mathrm{kg}$ of growth or weight gain are needed in this scenario. If the average cow gained $35 \mathrm{~kg}$ within a 330-d lactation, including fetal growth of the initial 7 mo of pregnancy (or $106 \mathrm{~g} / \mathrm{d}$ ), $0.6 \mathrm{~g}$ of $\mathrm{P}$ would be retained daily on average per cow, or $89 \mathrm{~g}$ for the entire herd. This amount only represents $0.63 \%$ of the $\mathrm{P}$ input and is smaller than the error term of $\mathrm{P}$ not accounted for in the outflow. And based on BW observations in the herd, $35 \mathrm{~kg}$ of growth is unlikely. Mean BW for the cows in the barn was relatively constant throughout the study averaging $563 \mathrm{~kg}$ on January 2, peaking at $573 \mathrm{~kg}$ on June 3, and falling to $558 \mathrm{~kg}$ on December 3 , thereby supporting the assumption that retained $\mathrm{P}$ could be ignored. When ignoring retained $\mathrm{P}$, the recovered portion of $\mathrm{P}$ accounts for $102 \%$ of $\mathrm{P}$ input, lending support to the accuracy of the estimations, assumptions, and sampling methods utilized in the current study.

On an individual cow basis, estimated $\mathrm{P}$ intake averaged $99.6( \pm 1.64) \mathrm{g} / \mathrm{d}$ (Figure 1$)$. An insignificant portion, $0.7( \pm 0.05) \mathrm{g} / \mathrm{d}$, is added from the bedding material. Cows in the 2005 ASAE standard data set consumed $96 \mathrm{~g}$ of $\mathrm{P} / \mathrm{d}$ and excreted $74( \pm 1.8) \mathrm{g}$ of $\mathrm{P} / \mathrm{d}$ (Nennich et al., 2005). In the current study, $74.8( \pm 4.17) \mathrm{g}$ of $\mathrm{P} / \mathrm{d}$ per cow were recovered in the outflow (Figure 1). With the addition of the $26.8( \pm 0.40) \mathrm{g}$ of secreted $\mathrm{P}$ exported 
in milk, the $\mathrm{P}$ leaving the system exceeded the input of $\mathrm{P}$ by an insignificant $2 \%$.

The 2005 ASAE standard reports 4 equations to predict $\mathrm{P}$ excretion $\left(\mathrm{P}_{\mathrm{E}}, \mathrm{g} / \mathrm{d}\right)$ in manure:

$$
\begin{gathered}
\mathrm{P}_{\mathrm{E}}=\mathrm{MY}(\mathrm{kg} / \mathrm{d}) \times 0.781+50.4 \\
\mathrm{P}_{\mathrm{E}}=\mathrm{DMI}(\mathrm{kg} / \mathrm{d}) \times \operatorname{dietary} \mathrm{P}[\mathrm{g} / \mathrm{g}] \\
\times 560.7+21.1 \\
\mathrm{P}_{\mathrm{E}}=\text { DMI }(\mathrm{kg} / \mathrm{d}) \times 1,000 \times \text { dietary } \mathrm{P}[\mathrm{g} / \mathrm{g}] \\
-\mathrm{Milk} \mathrm{P}(\mathrm{g} / \mathrm{d}) \\
\mathrm{P}_{\mathrm{E}}=7.5+\mathrm{DMI}(\mathrm{kg} / \mathrm{d}) \times \operatorname{dietary~} \mathrm{P}[\mathrm{g} / \mathrm{g}] \times 780 \\
-\mathrm{MY}(\mathrm{kg} / \mathrm{d}) \times 0.702
\end{gathered}
$$

where MY represented milk yield.

Equations [4] and [5] were derived from an original data set; eq. [6] and [7] were initially proposed elsewhere [Beede and Davidson (1999) and Weiss and Wyatt (2004), respectively]. Equation [4] uses milk yield, whereas the other 3 are based on intake of $P$ from the diet. It was previously observed that eq. [5] exhibited an improved prediction of $\mathrm{P}$ excretion compared with

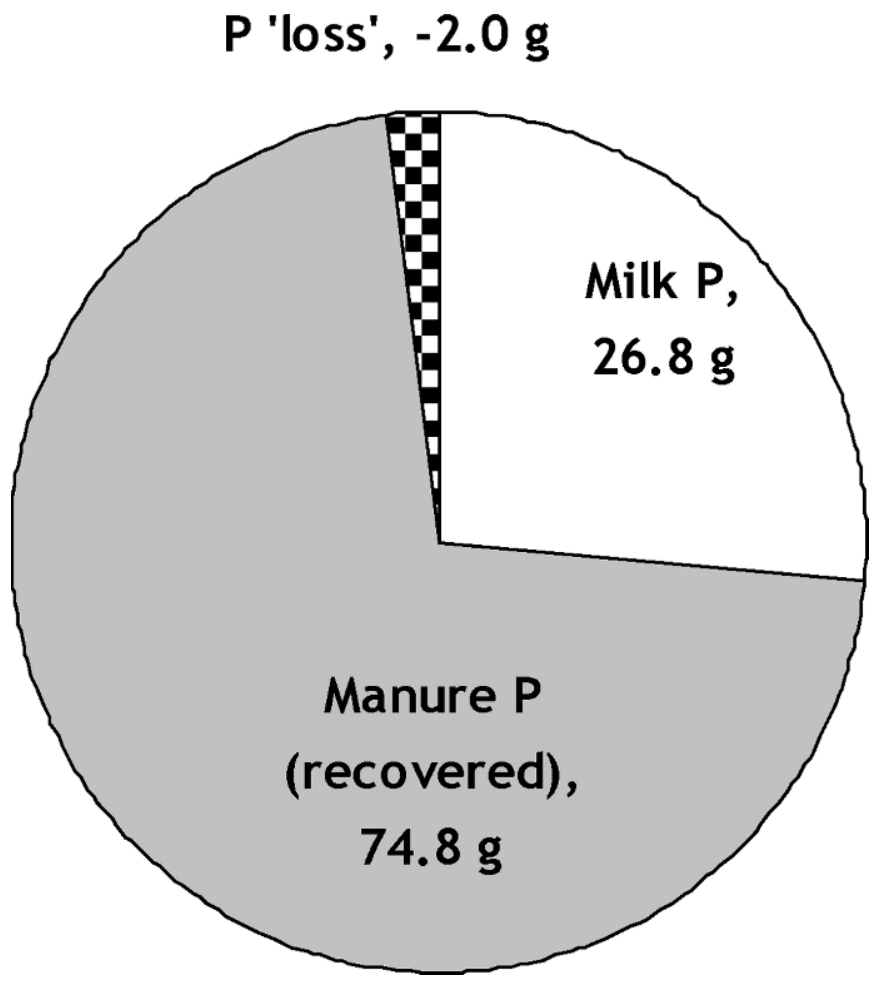

Figure 1. Fate of $\mathrm{P}$ inputs from feed and bedding in a lactating dairy cow. the milk yield-based eq. [4] (residual $\mathrm{SE}=9.7$ vs. 13.4 and interstudy $\mathrm{SE}=9.2$ vs. 11.3 , respectively; Nennich et al., 2005). Addition of a variable for $\mathrm{P}$ output in milk did not further improve eq. [5] (Nennich et al., 2005). Equation [6], proposed by Beede and Davidson (1999), simply states that dietary $\mathrm{P}$ intake equals $\mathrm{P}$ output in milk and manure, neglecting any $\mathrm{P}$ retention. Equation [7], established by Weiss and Wyatt (2004), used dietary $P$ intake and milk yield from Holstein and Jersey cows. Contrary to eq. [6], eq. [7] accounts for an inevitable P loss (intercept), but also incorporates a retention factor of $22 \%$ of dietary $\mathrm{P}$ intake.

Figure 2a represents the predicted $\mathrm{P}$ excretion vs. its residual (P recovered in the outflow minus the predicted $\mathrm{P}$ excretion) for each equation at every sampling day, and Figure 2b graphs residual vs. dietary $\mathrm{P}$ content. As an example, the black arrow in Figure 2a points to a datum derived from eq. [5]. The predicted $\mathrm{P}$ excretion for that sampling day was about $67 \mathrm{~g}$; however, the measured P outflow was $55 \mathrm{~g} / \mathrm{d}(67 \mathrm{~g}-12 \mathrm{~g})$. Thus, a negative residual signifies an overprediction of $\mathrm{P}$ excretion compared with the recovered $\mathrm{P}$ at a specific sampling date and vice versa. This may be due to bias in the prediction or sampling errors and variation within the biological system.

The residuals were distributed normally around their respective mean; however, individual measurements of $\mathrm{P}$ outflow varied by $16.6 \mathrm{~g}$ on a day-to-day basis (Table 3 ). The mean of the residuals ( \pm SEM) from eq. [4], which is based solely on milk yield, was $1.2( \pm 4.19) \mathrm{g} / \mathrm{d}$. Still, when the $\mathrm{P}$ content of the diets in the current study was reduced from 0.47 to $0.37 \%$ for the last 2 sampling periods, without affecting milk production per cow, the 2 corresponding data points for eq. [4] (inside the dotted circle) do not stand out in Figure 2a, but are obvious when plotted against dietary $\mathrm{P}$ in Figure $2 \mathrm{~b}$ when compared with the other 3 equations.

Nennich et al. (2005) suggested using milk yield as a predictor only if DMI or dietary $\mathrm{P}$ content data are not available. The authors based that proposition on the assumption that increased milk production leads to greater DMI (e.g., Allen, 2000), and hence increased $\mathrm{P}$ intake and excretion. This presumed linear increase in $\mathrm{P}$ consumption may hold true for an average or standard dietary $\mathrm{P}$ concentration. Yet this approach is inherently less precise than other methods because published research demonstrates consistently that reducing dietary $\mathrm{P}$ content to about $0.35 \%$ does not affect milk production but does significantly decrease $\mathrm{P}$ excretion, especially fecal $\mathrm{P}$ excretion. Cows directly excrete any $\mathrm{P}$ supplementation above requirement (Morse et al., 1992; Wu and Satter, 2000; Knowlton and Herbein, 2002). Thus, increasing dietary $P$ content above $0.35 \%$ does not affect milk production, yet increases $\mathrm{P}$ excre- 

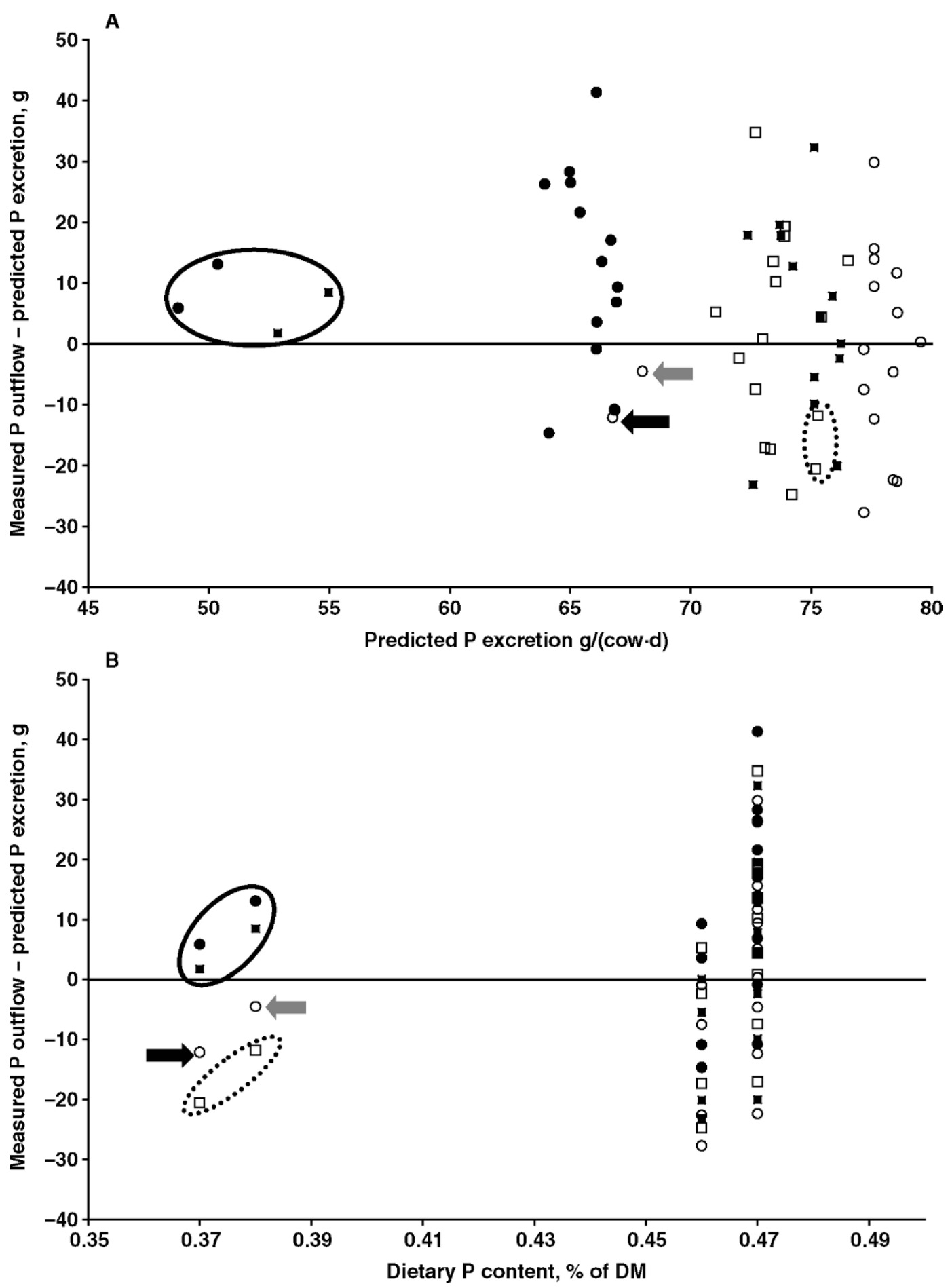

Figure 2. Residual plot by predicted amounts of P excretion (a) and by dietary P content (b), using eq. $4(\square)$, eq. $5(\bigcirc)$, eq. $6(\bullet)$, and eq. 7 ( $\mathbf{\square}$ ). Points encompassed in a solid line, a dotted line, or indicated by arrows represent sampling days when dietary $\mathrm{P}$ was 0.37 or $0.38 \%$ vs. 0.46 or $0.47 \%$ of $\mathrm{DM}$ for all other data points.

tion linearly. Accordingly, estimation of $\mathrm{P}$ excretions based solely on milk yield cannot reflect variation in $\mathrm{P}$ excretion because of possible changes in $\mathrm{P}$ intake nor can it be used as a tool to reduce $\mathrm{P}$ output from a system.
The other 3 equations are based either solely on dietary $\mathrm{P}$ intake (eq. [5]) or as a combination of dietary $P$ intake and milk yield (eq. [6] and [7]). Evaluation of the distribution of the residuals (Figure 2) revealed that 


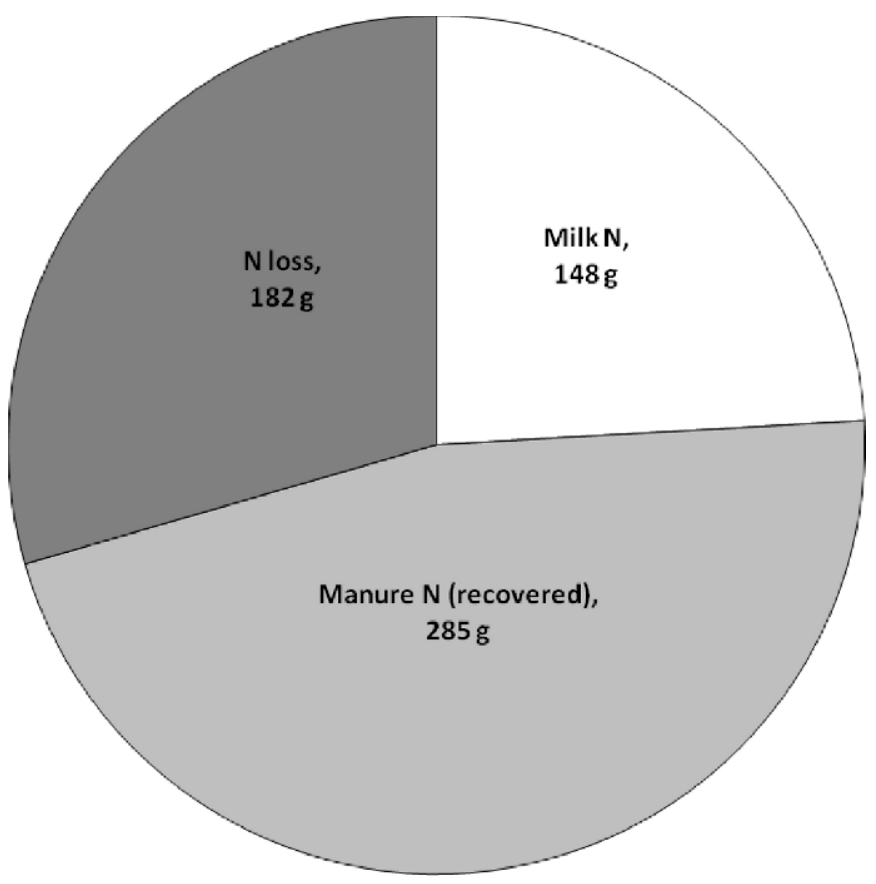

Figure 3. Fate of $\mathrm{N}$ inputs from feed and bedding in a lactating dairy cow. Daily input accumulated to an estimated $614 \mathrm{~g} / \mathrm{d}$ of dietary and bedding $\mathrm{N}$.

eq. [5] and [6] predicted $\mathrm{P}$ excretion as measured by $\mathrm{P}$ recovered in outflow of slurry accurately, whereas eq. [7] underpredicted $\mathrm{P}$ excretion. The mean biases $( \pm$ SEM) were $-1.8( \pm 3.93), 2.6( \pm 3.95)$, and $11.0( \pm 3.93)$ g/d for eq. [5], [6], and [7], respectively.

A solid circle encompasses the corresponding data points for eq. [6] and [7] (Figure 2), whereas the 2 arrows indicate the data points derived from eq. [5]. Inspection of Figure 2a and especially Figure $2 \mathrm{~b}$ discloses a shift of that pattern when dietary $\mathrm{P}$ content dropped to 0.37\%; eq. [6] predicted the observed $\mathrm{P}$ excretion most precisely. Although this observation is based on only 2 data points, the difference between equations would hold under similar initial values for dietary $\mathrm{P}$ intake and milk yield. Based upon our data set, eq. [4], [5], and [6] predicted the $\mathrm{P}$ outflow from the barn, but eq. [4] should be used cautiously.

\section{Predicted Excretion, Volatilization, and Recovery of $\mathbf{N}$}

The herd consumed on average $86.6( \pm 1.37) \mathrm{kg}$ of N/ $\mathrm{d}$, of which $20.9( \pm 0.54) \mathrm{kg}$ of $\mathrm{N} / \mathrm{d}$ were secreted in milk and $40.2( \pm 2.27) \mathrm{kg}$ of N/d were recovered immediately after flushing the barn. An individual cow consumed $614( \pm 2.1) \mathrm{g}$ of $\mathrm{N} / \mathrm{d}$, secreted $148( \pm 2.0) \mathrm{g}$ of $\mathrm{N} / \mathrm{d}$ in milk, and contributed $285( \pm 15.2) \mathrm{g}$ of $\mathrm{N} / \mathrm{d}$ to the outflow of slurry (Figure 3). Slurry nitrate and nitrite concen- trations were below detectable limits, so all slurry $\mathrm{N}$ was assumed to be organic or ammonia $\mathrm{N}$ and captured by the total Kjeldahl $\mathrm{N}$ analysis. The overall input of $\mathrm{N}$ from the bedding material was minute $(0.4 \mathrm{~g} / \mathrm{d}$ per cow). As a result, $25.5( \pm 2.44) \mathrm{kg}$ of $\mathrm{N} / \mathrm{d}$ or $182( \pm 16.3)$ $\mathrm{g}$ of $\mathrm{N} / \mathrm{d}$ per cow (30\% of $\mathrm{N}$ supplied in feed and bedding) were unaccounted for and were presumably lost to volatilization from the facility (Figure 3). As noted for $\mathrm{P}$ values, the increase in cow numbers in the facility influenced the magnitude of the SEM.

The ASAE (2005) standard contains 2 equations that were developed to calculate $\mathrm{N}$ excretion $\left(\mathrm{N}_{\mathrm{E}}\right)$ from lactating dairy cows (Nennich et al., 2005):

$$
\begin{gathered}
\mathrm{N}_{\mathrm{E}}(\mathrm{g} / \mathrm{d})=\mathrm{MY}(\mathrm{kg} / \mathrm{d}) \times 2.82+346 \\
\mathrm{~N}_{\mathrm{E}}(\mathrm{g} / \mathrm{d})=\mathrm{DMI}(\mathrm{kg} / \mathrm{d}) \times \text { dietary CP }[\mathrm{g} / \mathrm{g}] \\
\times 84.1+\mathrm{BW}(\mathrm{kg}) \times 0.196 .
\end{gathered}
$$

Equation [8] is solely based on milk yield, whereas eq. [9] is based on dietary $\mathrm{N}$ intake and BW. Equation [9] estimated $\mathrm{N}_{\mathrm{E}}$ more precisely than eq. [8] in the data set used to develop the 2005 ASAE standard (Nennich et al., 2005). The residual SE and interstudy SE for eq. [8] and [9] were 70.9 and 57.9, and 51.4 and 56.1, respectively. Surprisingly, the ASAE (2005) standard does not include equations estimating $\mathrm{N}_{\mathrm{E}}$ by means of $\mathrm{N}$ intake and $\mathrm{N}$ secretion. Given the intake and $\mathrm{BW}$ of cows in the current data set, eq. [8] yields an estimate of $430( \pm 1.1) \mathrm{g} / \mathrm{d}$ of $\mathrm{N}$ excreted per cow, whereas eq. [9] predicts $434( \pm 1.0) \mathrm{g} / \mathrm{d}$ of $\mathrm{N}$ excreted per cow for the current herd parameters (Tables 1 and 2). Assuming conservation of mass principles and insignificant $\mathrm{N}$ retention on a herd basis (with year-round calving), $\mathrm{N}$ intake minus $\mathrm{N}$ in milk should equal $\mathrm{N}$ excretion $\left(\mathbf{N}_{\mathbf{E}}\right)$ from the cow, as Van Horn (1994) previously suggested:

$$
\begin{gathered}
\mathrm{N}_{\mathrm{E}}(\mathrm{g} / \mathrm{d})=\mathrm{DMI}(\mathrm{g} / \mathrm{d}) \times \operatorname{diet} \mathrm{CP}[\mathrm{g} / \mathrm{g}] / 6.25 \\
-\mathrm{MY}(\mathrm{g} / \mathrm{d}) \times \text { milk protein }[\mathrm{g} / \mathrm{g}] / 6.38
\end{gathered}
$$

Later, Jonker et al. (1998) and Kohn et al. (2002) used individual MUN values to predict urinary $\mathrm{N}_{\mathrm{E}}$; however, total $\mathrm{N}_{\mathrm{E}}$ was based on a mass balance approach identical to [10]. Using eq. [10], $\mathrm{N}$ excretion was found to be $466( \pm 3.4) \mathrm{g} / \mathrm{d}$ per cow (Table 3$)$, which is $7 \%$ greater than that predicted by either eq. [8] or [9].

However, only $285( \pm 15.2) \mathrm{g}$ of $\mathrm{N}$ per cow were recovered in the manure outflow; significantly less than predicted from eq. [8], [9], and [10]. On the basis of using $P$ as a validative marker, we can assume that the difference in $\mathrm{N}_{\mathrm{E}}$ and recovery in flushwater represented $\mathrm{N}$ volatilization, which equated to $38.8 \%$ of the excreted $\mathrm{N}$ based on eq. [10] estimates. Theoretically, and in 


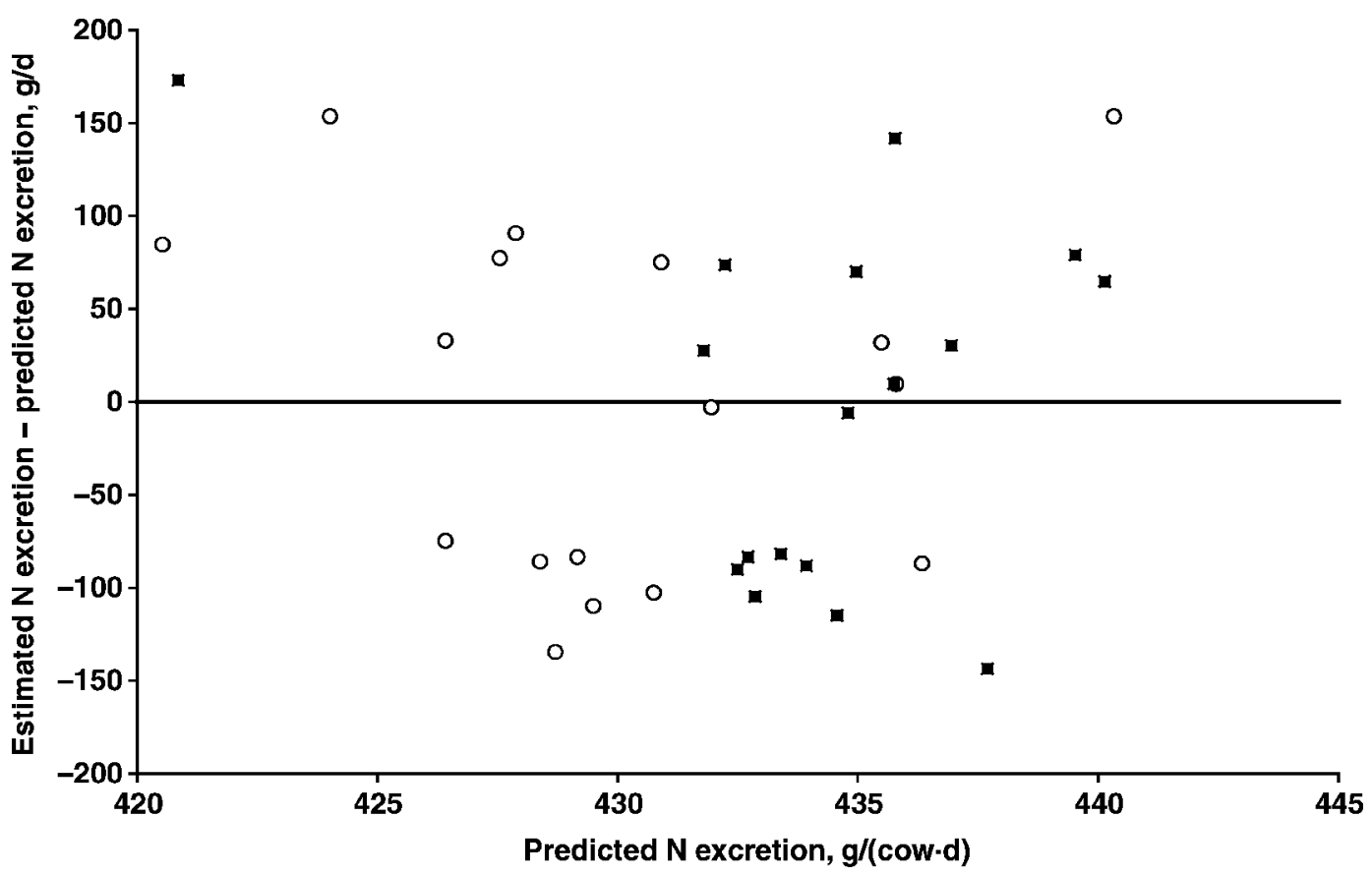

Figure 4. Estimated N excretion in comparison to predicted $\mathrm{N}$ excretion, assuming a $34 \% \mathrm{~N}$ loss. Use of a volatilization estimate of $34 \%$ resulted in an overall mean bias of $0 . \bigcirc=$ prediction eq. [8]; $\mathbf{\square}=$ prediction eq. [9].

accordance with Moreira and Satter (2006), this loss should be the true volatilization rate of $\mathrm{N}$.

Figure 4 illustrates the relationship of eq. [8] and [9] to observed $\mathrm{N}$ excreted as determined from wastewater assuming $34 \%$ of the excreted $\mathrm{N}$ is volatilized in the barn. Thirty-four percent was the value needed to remove mean bias from the predictions. If $\mathrm{N}$ excretion is accurately estimated from eq. [10], then this volatilization rate represents an underestimate of the true rate. The ASAE (2005) standard prediction equations are compared with $\mathrm{N}$ excreted as calculated from eq. [10] in Figure 5. The solid trendline (Figure 5) represents $\mathrm{X}=\mathrm{Y}$; for example, where the ASAE (2005) standard prediction equals $\mathrm{N}$ excretion calculated from eq. [10]. All but one datum are above the $\mathrm{X}=\mathrm{Y}$ line, reiterating that both eq. [8] and [9] underestimate $\mathrm{N}$ excretion compared with the mass balance approach. Furthermore, Figure 5 demonstrates the individual shortcomings of eq. [8] and [9]. Data points of eq. [8] have a negative slope, as shown by its trendline $\left(\mathrm{r}^{2}=0.54\right)$. Because eq. [8] is linearly based on raw milk yield, it predicted increased $\mathrm{N}$ excretion as milk yield increased over the course of the study year, whereas $\mathrm{N}$ excretion actually declined as $\mathrm{N}$ efficiency presumably increased. Equation [9] underpredicted $\mathrm{N}$ excretion overall, but did not exhibit any slope bias. The underpredictions of eq. [9] could have resulted from failure to consider milk protein output. The greatest $\mathrm{N}$ efficiency, but not neces- sarily the greatest production, is a result of a combination of limited $\mathrm{N}$ intake and high milk production (StPierre, 2001). Consequently, an equation predicting N excretion and losses ought to be founded on both $\mathrm{N}$ intake and milk yield.

Several other researchers have attempted to model N excretion. Wilkerson et al. (1997) used a data set based on several feeding trials to establish a linear equation. Cows included in that data set produced 22.8 $\mathrm{kg}$ of milk/d with $3.2 \%$ protein and $3.6 \%$ fat and consumed $16.2 \mathrm{~kg}$ of DM/d containing $16.1 \% \mathrm{CP}$. Production, DMI, and CP content of the diets were, on average, lower than in the database of Nennich et al. (2005) and the current study. Using our parameters in the equation of Wilkerson et al. (1997) resulted in predicted excretion of $365( \pm 1.8) \mathrm{g}$ of $\mathrm{N} / \mathrm{d}$, significantly less than predictions using the ASAE (2005) standard (Nennich et al., 2005) and that calculated from eq. [10] herein. Nevertheless, cows in the former report had lower $\mathrm{N}$ intake overall $(417 \mathrm{~g} / \mathrm{d})$ and $\mathrm{N}$ output in milk (115 g/d) than the cows combined for the ASAE (2005) standard (608 and $148 \mathrm{~g} / \mathrm{d}$, respectively) and in the current study (614 and $148 \mathrm{~g} / \mathrm{d}$, respectively). In addition, the cows of Wilkerson et al. (1997) were more efficient, converting $28 \%$ of dietary $\mathrm{N}$ to milk $\mathrm{N}$ vs. $24 \%$ conversion for the observations of Nennich et al. (2005) and the current observations. The ASAE (2005) standard also 


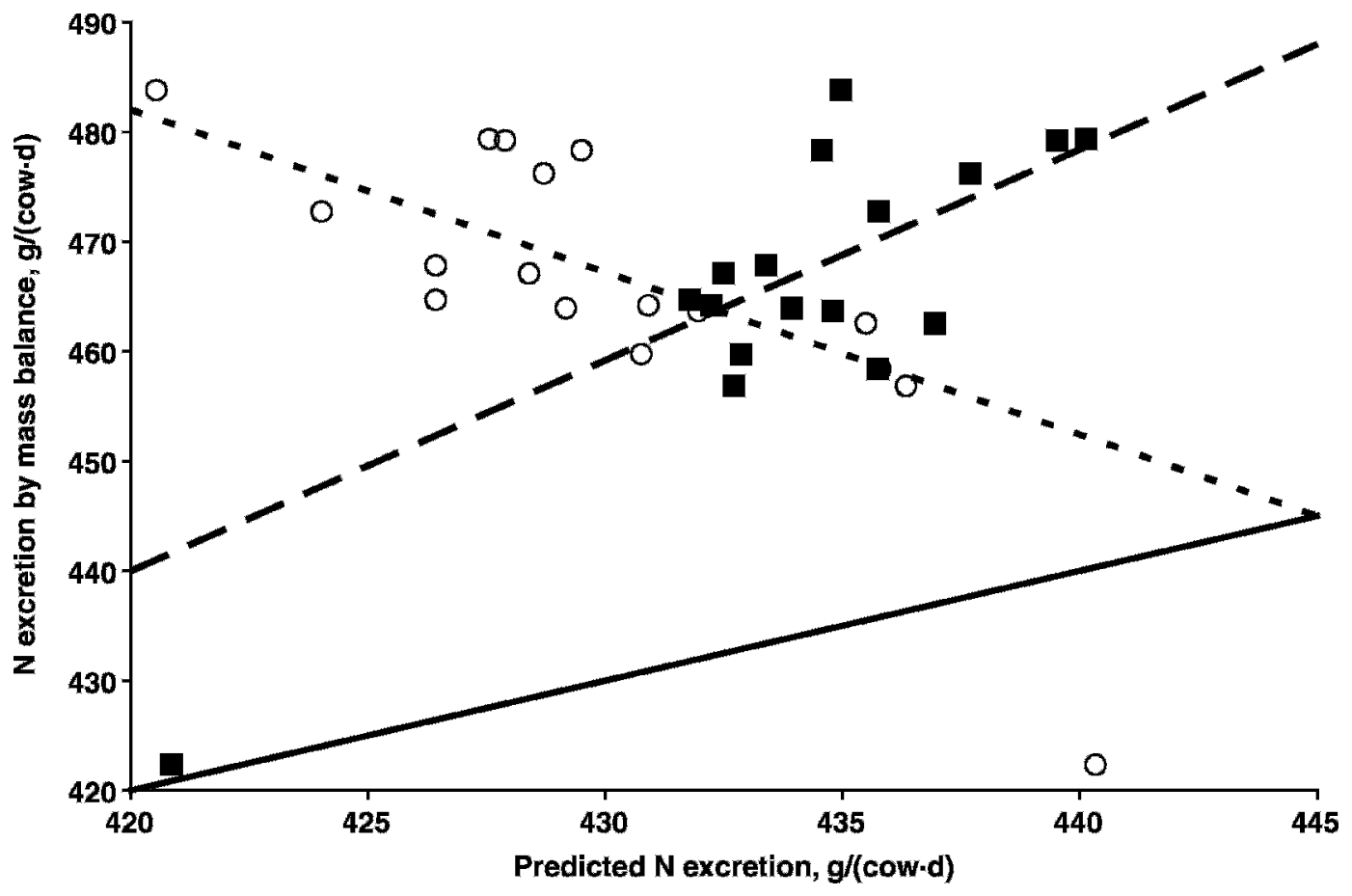

Figure 5. Excreted $\mathrm{N}$ as estimated by mass balance in comparison to predicted $\mathrm{N}$ excretion assuming a $34 \% \mathrm{~N}$ loss. $\bigcirc=$ prediction eq. [5]; = prediction eq. [6]. Solid line: $\mathrm{X}=\mathrm{Y}$; dotted line: trendline for eq. [8], $\mathrm{r}^{2}=0.54$; dashed line: trendline for eq. [9], $\mathrm{r}^{2}=0.33$. The 2 data points at $\mathrm{Y}=422 \mathrm{~g}$ of $\mathrm{N}$ were omitted for trendlines because of high leverage.

reported a significant difference between their equations and the Wilkerson equation.

Recently, Yan et al. (2006) developed an equation explaining $\mathrm{N}$ excretion solely as a portion of $\mathrm{N}$ intake $\left(\mathrm{r}^{2}=0.90\right)$ :

$$
\mathrm{N}_{\mathrm{E}}=0.722 \times \text { dietary CP }[\mathrm{g} / \mathrm{g}] .
$$

Diets fed in their studies included a significant amount of grass silage and thus, dietary $\mathrm{N}$ was highly degradable. Applying eq. [11] to our herd data resulted in predicted $\mathrm{N}$ excretion of $444( \pm 1.5) \mathrm{g} / \mathrm{d}$, which was $22 \mathrm{~g}$ less than the observed value. Contrary to the ASAE (2005) standard, Yan et al. (2006) observed that milk yield was a weak, though significant, predictor of $\mathrm{N}$ excretion $\left(\mathrm{r}^{2}=0.32\right)$. However, milk production was lower $(21.4 \pm 6.6 \mathrm{~kg} / \mathrm{d})$ and dietary CP greater $(18.3 \pm$ $2.6 \%$ ) than in the data set utilized by Nennich et al. (2005). As a result, Yan et al. (2006) detected a greater urine-N to fecal-N ratio (3:2) than Nennich et al. (2005; 1:1). The cows in the data set of Yan et al. (2006) most likely consumed $\mathrm{N}$ above requirements, increasing urine-N disproportionately without affecting milk true protein secretion. Nonetheless, $\mathrm{N}$ excretion calculated using our herd parameters and eq. [11] were only 1.6 and $1.0 \%$ greater than based on eq. [8] and [9], respectively.
Equation [10] was originally derived from data by Tomlinson (1992), where $\mathrm{N}_{\mathrm{E}}$ was best predicted by:

$$
\begin{aligned}
\mathrm{N}_{\mathrm{E}}= & 0.778 \times \mathrm{N} \text { intake }(\mathrm{g})-6.93 \\
& \times \mathrm{DMI}(\mathrm{kg})+122.61
\end{aligned}
$$

Equation [12] predicts $450( \pm 1.5) \mathrm{g}$ of daily $\mathrm{N}_{\mathrm{E}}$ when our input data are used resulting in an apparent volatilization loss of $36.7 \%$.

Cabrera et al. (2006) simulated $\mathrm{N}$ excretion for dairy farms in northern Florida using NRC (2001) recommendations for $\mathrm{CP}$ content in the diet (15.0 and 13.9\%). For the rolling herd average of the current herd $(9,000 \mathrm{~kg})$, the model of Cabrera et al. (2006) predicts a daily $\mathrm{N}$ excretion of between $307 \mathrm{~g} / \mathrm{cow}$ (August) and $323 \mathrm{~g} /$ cow (February).

With one exception, manure-N outflow per cow was lowest among all sampling days from mid April to September $(<250 \mathrm{~g} / \mathrm{d})$, whereas $\mathrm{N}$ recovery in the slurry was above $250 \mathrm{~g} / \mathrm{d}$ for January through March and October to December 2005 of the current study. Diets used in the current study averaged $17.7 \% \mathrm{CP}$, similar to the $17.2 \% \mathrm{CP}$ average reported for herds in Wisconsin (Powell et al., 2006), and resembling common practices in the field. The simulation forecasted greater amounts of $\mathrm{N}$ excreted during winter and spring. Milk production 
peaks during that same time frame (Cabrera et al., 2006); the increased milk yield increases DMI. Consequently, more $\mathrm{N}$ is taken up but usage of that additional $\mathrm{N}$ is not $100 \%$ efficient, leading to increased $\mathrm{N}$ excretion (Wilkerson et al., 1997; Cabrera et al., 2006). This seasonal effect was indirectly supported by Powell et al. (2006), who reported the greatest $\mathrm{N}$ content of semisolid manure in March and May, when manure samples were collected every other month across $1 \mathrm{yr}$. An increasing rate of $\mathrm{N}$ volatilization during summer months because of increased ambient temperature may also explain our seasonal observations.

\section{Dynamics of N Partitioning and Volatilization}

It is noteworthy that $\mathrm{N}$ volatilization is not a linear process. James et al. (1999) found that over 90\% of ammonia volatilization over the initial 65 -h postexcretion period occurred during the first $26 \mathrm{~h}$. The flush frequency for this work was $6 \mathrm{~h}$; hence, manure remained in the alleys for an average of $3 \mathrm{~h}$ from excretion to removal by the flush. For the specific setup in the study - using recycled wastewater to flush every $6 \mathrm{~h}-$ $\mathrm{N}$ volatilization accounted for $38.8 \%$ of excreted $\mathrm{N}$.

Because we were able to recover all $\mathrm{P}$ entering the system, we are confident that unaccounted $\mathrm{N}$ describes the apparent $\mathrm{N}$ volatilization during an average 3-h time interval between excretion and sampling (Moreira and Satter, 2006). Some additional N may have been volatilized from the recycled flush water due to agitation of the water and exposure to air during the flush event, because the flushwater contained $387( \pm 13.1) \mathrm{mg} /$ $\mathrm{L}$ and contributed approximately $74.0( \pm 5.79) \mathrm{kg} / \mathrm{d}$ of the $93.5( \pm 7.59) \mathrm{kg} / \mathrm{d}$ of ammonia recovered in the outflow. Although this amount was subtracted from the ammonia outflow, some of the flushwater ammonia-N may have been volatilized because of turbulence during the flush.

Urease found in feces and the environment catalyzes the conversion of urine urea- $\mathrm{N}$ to ammonia. Ammonia volatilization from sheep manure peaked within 1 to 3 d postexcretion (Machmüller et al., 2006) and within 10 to $15 \mathrm{~h}$ from dairy heifer manure (James et al., 1999). Organic $\mathrm{N}$ is converted to ammonia and consequently volatilized at a much slower rate of $1.5 \% \mathrm{~N} / \mathrm{d}$ (Meisinger et al., 2001). Excreted N, therefore, may be grouped into potential short-term $\mathrm{N}$ loss and longer-term $\mathrm{N}$ loss. The potential for manipulating $\mathrm{N}$ losses postexcretion via management and treatment choices may be greater for the longer-term than the (probably inevitable) shortterm $\mathrm{N}$ losses. Thus, quantification of urine- $\mathrm{N}$ or specifically urea-N as the major contributor to short-term $\mathrm{N}$ loss may be warranted.
Urea excretion increases when ammonia, predominantly originating from excess dietary protein, is converted to urea and excreted in urine. The partition of excreted $\mathrm{N}$ among feces and urine, and thus urea-N, depends on dietary CP consumption (Castillo et al., 2000; Marini and Van Amburgh, 2005), the digestibility of that CP, AA use by the animal for productive purposes, and to a lesser extent, protein degradability in the rumen (Castillo et al., 2001). Wilkerson et al. (1997) observed that in cows fed common diets, $50 \%$ of $\mathrm{N}$ was excreted as urinary- $\mathrm{N}$, as was the case in the foundation database for the 2005 ASAE standard (Nennich et al., 2005). According to the NRC (2003), slightly more N is excreted in feces than in urine when lactating cows are fed $8 \%$ above their protein requirement (NRC, 2003). When dietary CP was increased from 11 to 15 and $19 \%$ in lactating dairy cows, the portion of $\mathrm{N}$ excreted in urine of the total excreted $\mathrm{N}$ increased from 27.2 to 39.2 and $48.5 \%$, respectively (Baik et al., 2006). Other researchers reported 58 and $63 \%$ of excreted $\mathrm{N}$ in the urine (Castillo et al., 2001; VandeHaar and St-Pierre, 2006). Generally, the amount of both fecal-N and urine$\mathrm{N}$ increases linearly at increasing amounts of total $\mathrm{N}$ excretion but the slope for urine- $\mathrm{N}$ is much greater (Tomlinson, 1992; Baik et al., 2006). Thus, partitioning of $\mathrm{N}$ excretion is not static, but depends on the total amount of $\mathrm{N}$ excreted, which is itself correlated to $\mathrm{N}$ intake. From this standpoint, urea excretion may be viewed as a crude estimator of $\mathrm{N}$ efficiency, but there is no firm ratio of partition of excreted $\mathrm{N}$; rather, the urine-N-to-fecal-N ratio depends on dietary and animal factors.

In our scenario, $40.24 \mathrm{~kg}$ of $\mathrm{N}$ was recovered in the wastewater leaving the barn, whereas we estimated that $68.84 \mathrm{~kg}$ of $\mathrm{N}$ was excreted (Figure 3). Given the rate of manure deposition and $\mathrm{N}$ collected in a flush cycle, the rate of volatilization can be calculated:

$$
\mathrm{A}=\mathrm{B} \times\left[1-\mathrm{e}^{(-\mathrm{k} \times \mathrm{t})}\right] / \mathrm{k}
$$

where $\mathrm{A}$ is the recovered amount of $\mathrm{N}$ in flush water $(\mathrm{kg} / 6 \mathrm{~h}), \mathrm{B}$ the rate of $\mathrm{N}$ excretion $(\mathrm{kg} / \mathrm{h}), \mathrm{k}$ is the hourly volatilization rate $\left(h^{-1}\right)$, and the time interval for flushing ( $6 \mathrm{~h}$ ). From eq. [13], it was determined that the rate of volatilization was $18.1 \pm 2.2 \% / \mathrm{h}$. Based on previous work, virtually all volatilized $\mathrm{N}$ in this short period originates from urea $\mathrm{N}$ in urine (Meisinger et al., 2001).

Many approaches have been proposed to predict urea excretion and short-term ammonia losses from manure. In cattle, urea-N as a proportion of urine- $\mathrm{N}$ ranged from 68 to 93\% (Bristow et al., 1992). Later, de Boer et al. (2002) observed that dairy cows excreted a fixed amount of nonurea $\mathrm{N}$ compounds in urine, primarily allantoin 
and creatinine. The authors concluded that excretion of urea- $\mathrm{N}$ was not fixed, but could be predicted as 0.86 $\times$ urine-N concentration ( $\mathrm{g}$ of $\mathrm{N} / \mathrm{kg}$ of urine) -1.16 (de Boer et al., 2002). Kohn et al. (2002) established a formula using MUN and BW to predict urinary $\mathrm{N}$ excretion. Using that formula, 239 ( \pm 10.1$) \mathrm{g}$ of urinary N/ cow per $d$ would be predicted to be excreted in the current herd. Total $\mathrm{N}$ excretion from the herd was 466 $\mathrm{g} / \mathrm{d}$ on a per-cow basis [10], leading to a 51:49 urine-N to fecal-N ratio. Given the $\mathrm{N}$ volatilization rate in the current study and assuming urine-N was $86 \%$ urea-N, urea-N volatilization across the 6 -h flush interval was $86 \%$. Because of the previously established nonlinearity of urea excretion, we propose that a model that predicts excretion of $\mathrm{N}$ and volatilization of $\mathrm{N}$ from manure must account for $\mathrm{N}$ intake, $\mathrm{N}$ demand from production, and consequent partitioning of excreted $\mathrm{N}$ (i.e., fecal-N, urea-N, nonurea urine-N). Generally, $\mathrm{N}$ fluxes and losses need to be evaluated from a holistic view of the entire dairy community, because overall $\mathrm{N}$ efficiency is maximized when the least amount of $\mathrm{N}$ is excreted per volume of milk production (St-Pierre, 2001).

\section{CONCLUSIONS}

We were unable to recover the amount of solids in the outflow predicted by the recently published (2005) ASAE standard (Nennich et al., 2005), partly because of differences in methods to determine manure solids across disciplines. Adoption of a uniform method for dry solids determination in manure is therefore warranted. All P flowing into the system was apparently recovered in the outflow of milk and manure. Yet, $182 \mathrm{~g} / \mathrm{d}$ of $\mathrm{N}$ per cow or $29.4 \%$ of the input $\mathrm{N}$ was not accounted for. This amount of $\mathrm{N}$ encompasses $38.8 \%$ of the excreted $\mathrm{N}$. Virtually all $\mathrm{N}$ excretion models appeared to underestimate $\mathrm{N}$ excretion. Overall, the rate of $\mathrm{N}$ volatilization was $18.1 \% / \mathrm{h}$. Future studies may measure urine-N, urea-N, or both, to allow greater precision in estimating volatilization rate of urea-N.

\section{ACKNOWLEDGMENTS}

We greatly appreciate suggestions by J. France and the help from the farm crew at the Virginia Tech Dairy Center under the direction of Harold Nester and Shane Brannock. We value the assistance of Weston Mims and numerous undergraduate and graduate students during the samplings of the manure system, including Katie Campbell, Aaron Cornman, Michael Guard, Stephanie Hill, Chris Lilly, Shane Martin, Kristen Pence, Shelly Slemp, Megan Taylor, Tracy Webb, Tzu-Hsuan Yang, and Zunyang Zhao. Laboratory analysis was conducted by and under the supervision of Cathy Parsons.
We appreciate financial support from Integrity Nutrient Control System (Chambersburg, PA). Marcus Hollmann was funded by a John Lee Pratt fellowship in animal nutrition.

\section{REFERENCES}

AFIA. 2007. Evaluation of analytical methods for analysis of dried distillers grains with solubles. American Feed Industry Association, Arlington, VA.

Allen, M. S. 2000. Effects of diet on short-term regulation of feed intake by lactating dairy cattle. J. Dairy Sci. 83:1598-1624.

AOAC. 1990. Official Methods of Analysis. 14th ed. Association of Official Analytical Chemists, Arlington, VA.

APHA. 1998. Standard methods for the examination of water and wastewater. 20th ed. American Public Health Association, Washington, DC.

ASAE. 1999. Manure production and characteristics. American Society of Agricultural Engineers, St. Joseph, MI.

ASAE. 2005. Manure production and characteristics. American Society of Agricultural Engineers, St. Joseph, MI.

Baik, M., J. R. Aschenbach, M. J. VandeHaar, and J. S. Liesman. 2006. Effect of dietary protein levels on milk production and nitrogen efficiency in dairy cattle. J. Anim. Sci. 84(Suppl. 1):81. (Abstr.)

Beede, D. K., and J. A. Davidson. 1999. Phosphorus: Nutritional management for Y2K and beyond. Proc. Tri-State Dairy Nutr. Conf. The Ohio State Univ., Columbus.

Bristow, A. W., D. C. Whitehead, and J. E. Cockburn. 1992. Nitrogenous constituents in the urine of cattle, sheep and goats. J. Sci. Food Agric. 59:387-394.

Cabrera, V. E., A. de Vries, and P. E. Hildebrand. 2006. Prediction of nitrogen excretion in dairy farms located in North Florida: A comparison of three models. J. Dairy Sci. 89:1830-1841.

Castillo, A. R., E. Kebreab, D. E. Beever, J. H. Barbi, J. D. Sutton, H. C. Kirby, and J. France. 2001. The effect of protein supplementation on nitrogen utilization in lactating dairy cows fed grass silage diets. J. Anim. Sci. 79:247-253.

Castillo, A. R., E. Kebreab, D. E. Beever, and J. France. 2000. A review of efficiency of nitrogen utilisation in lactating dairy cows and its relationship with environmental pollution. J. Anim. Feed Sci. 9:1-32.

de Boer, I. J. M., M. C. J. Smits, H. Mollenhorst, G. van Duinkerken, and G. J. Monteny. 2002. Prediction of ammonia emission from dairy barns using feed characteristics part 1: Relation between feed characteristics and urinary urea concentration. J. Dairy Sci. 85:3382-3388.

Hindrichsen, I. K., H. R. Wettstein, A. Machmüller, and M. Kreuzer. 2006. Methane emission, nutrient degradation and nitrogen turnover in dairy cows and their slurry at different milk production scenarios with and without concentrate supplementation. Agric. Ecosyst. Environ. 113:150-161.

James, T., D. Meyer, E. Esparza, E. J. Depeters, and H. Perez-Monti. 1999. Effects of dietary nitrogen manipulation on ammonia volatilization from manure from Holstein heifers. J. Dairy Sci. 82:2430-2439.

Jonker, J. S., R. A. Kohn, and R. A. Erdman. 1998. Using milk urea nitrogen to predict nitrogen excretion and utilization efficiency in lactating dairy cows. J. Dairy Sci. 81:2681-2692.

Knowlton, K. F., and J. H. Herbein. 2002. Phosphorus partitioning during early lactation in dairy cows fed diets varying in phosphorus content. J. Dairy Sci. 85:1227-1236.

Kohn, R. A., K. F. Kalscheur, and E. Russek-Cohen. 2002. Evaluation of models to estimate urinary nitrogen and expected milk urea nitrogen. J. Dairy Sci. 85:227-233.

Machmüller, A., D. A. Ossowski, and M. Kreuzer. 2006. Effect of fat supplementation on nitrogen utilisation of lambs and nitrogen emission from their manure. Livest. Sci. 101:159-168. 
Marini, J. C., and M. E. Van Amburgh. 2005. Partition of nitrogen excretion in urine and the feces of Holstein replacement heifers. J. Dairy Sci. 88:1778-1784.

Meisinger, J. J., A. M. Lefcourt, and R. B. Thompson. 2001. Construction and validation of small mobile wind tunnels for studying ammonia volatilization. Appl. Eng. Agric. 17:375-381.

Moreira, V. R., and L. D. Satter. 2006. Effect of scraping frequency in a freestall barn on volatile nitrogen loss from dairy manure. J. Dairy Sci. 89:2579-2587.

Morse, D., H. H. Head, C. J. Wilcox, H. H. Van Horn, C. D. Hissem, and B. Harris. 1992. Effects of concentration of dietary phosphorus on amount and route of excretion. J. Dairy Sci. 75:3039-3049.

Nennich, T. D., J. H. Harrison, L. M. VanWieringen, D. Meyer, A. J. Heinrichs, W. P. Weiss, N. R. St-Pierre, R. L. Kincaid, D. L. Davidson, and E. Block. 2005. Prediction of manure and nutrient excretion from dairy cattle. J. Dairy Sci. 88:3721-3733.

NRC. 2003. Air Emissions from Animal Feeding Operations. Natl. Acad. Sci., Washington, DC.

Powell, J. M., D. B. Jackson-Smith, D. F. McCrory, H. Saam, and M. Mariola. 2006. Validation of feed and manure data collected on Wisconsin dairy farms. J. Dairy Sci. 89:2268-2278.

St-Pierre, N. R. 2001. Economic factors affecting nutrient balance on dairy farms. Adv. Dairy Technol. 13:263-281.
Tomlinson, A. P. 1992. Effects of increasing undegradable protein, with and without supplemental fat, on milk production and composition and physiological responses of the lactating dairy cow. MS Thesis. Univ. Florida, Gainesville.

VandeHaar, M. J., and N. R. St-Pierre. 2006. Major advances in nutrition: Relevance to the sustainability of the dairy industry. J. Dairy Sci. 89:1280-1291.

Van Horn, H. H., A. C. Wilkie, W. J. Powers, and R. A. Nordstedt. 1994. Components of dairy manure management-systems. J. Dairy Sci. 77:2008-2030.

Weiss, W. P., and D. J. Wyatt. 2004. Macromineral digestion by lactating dairy cows: Estimating phosphorus excretion via manure. J. Dairy Sci. 87:2158-2166.

Wilkerson, V. A., D. R. Mertens, and D. P. Casper. 1997. Prediction of excretion of manure and nitrogen by Holstein dairy cattle. J. Dairy Sci. 80:3193-3204.

Wu, Z., and L. D. Satter. 2000. Milk production and reproductive performance of dairy cows fed two concentrations of phosphorus for two years. J. Dairy Sci. 83:1052-1063.

Yan, T., J. P. Frost, R. E. Agnew, R. C. Binnie, and C. S. Mayne. 2006. Relationships among manure nitrogen output and dietary and animal factors in lactating dairy cows. J. Dairy Sci. 89:3981-3991. 